\title{
SHARED WEB INFORMATION SYSTEMS FOR HERITAGE IN SCOTLAND AND WALES - FLEXIBILITY IN PARTNERSHIP.
}

\author{
D. Thomas ${ }^{a}$, P.McKeague ${ }^{\text {b* }}$ \\ Royal Commission on the Ancient and Historical Monuments of Wales, \\ Plas Crug, Aberystwyth, SY23 1NJ, Wales, UK- \\ david.thomas@rcahmw.gov.uk \\ ${ }^{\mathrm{b}}$ Royal Commission on the Ancient and Historical Monuments of Scotland, \\ John Sinclair House, 16 Bernard Terrace, Edinburgh EH8 9NX, Scotland, UK - \\ peter.mckeague@rcahms.gov.uk
}

KEY WORDS: Cultural Heritage, Inventory, Data, Information, Internet/Web

\begin{abstract}
:
The Royal Commissions on the Ancient and Historical Monuments of Scotland and Wales were established in 1908 to investigate and record the archaeological and built heritage of their respective countries. The organisations have grown organically over the succeeding century, steadily developing their inventories and collections as card and paper indexes. Computerisation followed in the late 1980s and early 1990s, with RCAHMS releasing Canmore, an online searchable database, in 1998. Following a review of service provision in Wales, RCAHMW entered into partnership with RCAHMS in 2003 to deliver a database for their national inventories and collections. The resultant partnership enables both organisations to develop at their own pace whilst delivering efficiencies through a common experience and a shared IT infrastructure. Through innovative solutions the partnership has also delivered benefits to the wider historic environment community, providing online portals to a range of datasets, ultimately raising public awareness and appreciation of the heritage around them. Now celebrating its 10th year, Shared Web Information Systems for Heritage, or more simply SWISH, continues to underpin the work of both organisations in presenting information about the historic environment to the public.
\end{abstract}

\section{THE PARTNERSHIP}

Shared Web Information Systems for Heritage (SWISH) is a partnership between the Royal Commissions on the Ancient and Historical Monuments of Scotland (RCAHMS) and Wales (RCAHMW). Both organisations were established in 1908 to record and survey the heritage of their respective countries and now operate as sponsored bodies supported by their devolved governments. The National Collections or National Monuments Records of Scotland and Wales form the core of both organisations' work, and each encompasses a site inventory linked to an extensive archive. Both archives are recognised by The National Archives as 'places of deposit'. Of the two organisations, the Scottish Commission is the larger, with around 100 staff and a database that encompasses information on around 320,000 sites, and with an integrated archive of over $1,190,000$ catalogued items. The Welsh Commission retains approximately 35 staff and has information on just over 100,000 sites, with a related archive of over 362,000 items.

Governance of SWISH is shared equally between the two organisations and is guided by a steering group made up of selected Commissioners and staff from the two organisations. Programme management is undertaken by a shared board that meets every six months and staff involved in individual projects meet at least once a month.

\subsection{From paper to digital}

Although both the Scottish and Welsh Commissions have a long and distinguished background in archaeological and architectural field survey and publication through their respective inventory series, it is the former Ordnance Survey Archaeology Division's card index and recording system that forms the kernel of the computerised databases in use today (Dunbar 1992). Used across Britain, the card indexes were initially designed to assist with the selection of sites for depiction as antiquities on Ordnance Survey maps. The cards gave a structure to information and a provided a more complete coverage of each nation's heritage than the intensive character of the inventories (Murray 1992, 210)

From the late 1980s both organisations recognised the need to computerise their records, with RCAHMS transferring their card index records into a STAIRS database by 1988 In Wales, a bespoke system was developed in FoxPro in 1992 to support the internal information management needs of the Commission in the pre-internet era. The system was further developed as the basis for information exchange between organisations engaged in managing records of the historic environment in Wales, including the archaeological trusts and Cadw, the Welsh Government's Historic Environment Service. An on-line index to the shared information, known as CARN, was first published in 1999 (Nikolic 1999). The decision in Scotland to move to an

\footnotetext{
* Corresponding author
} 
Oracle solution by 1990 provided a solid platform to build a robust relational database capable of handling many thousands of records and relationships documenting site, collection and bibliographic references. The development included the management of links to related databases, such as those maintained by Historic Scotland to manage statutory data about Scheduled Monuments or Listed Buildings. The arrangement allows each organisation to manage the information they are directly responsible for but also easily view related data (Byrne 1999, Ashmore, 1992, Murray 1992). In 1998, RCAHMS was amongst the first national agencies to publish their database online, through Canmore (http://canmore.rcahms.gov.uk), complemented by the release of a Web-GIS browser in 2003.

\subsection{Development of the partnership}

The SWISH partnership developed from an Information Systems Strategy Review at RCAHMW in 2001 that recognised the need to upgrade the platform for managing the data and archive content of the National Monuments Record of Wales. A subsequent business case identified four options: develop existing RCAHMW systems; buy an 'off-the-shelf' system; develop a bespoke system through a software developer; or identify an existing system that could be adapted. The most obvious candidate for the latter was the system used by the Scottish Royal Commission, developed in Oracle with a wellestablished web presence in Canmore, and this was recognised as the best option to pursue. For Wales the partnership offered a number of long-term benefits. These included development work, maintenance and data storage and security managed remotely. The solution provided an integrated data system, encouraging standardisation and consistency of data through database upgrades that could be used by all staff and, crucially, development of online resources. For Scotland, working in partnership strengthened the development team based in Edinburgh, reduced development time through economies of scale, as well as increasing resilience and standardisation of systems. The partnership would provide a platform to enhance existing developments and develop new applications (Malaws $e t$ al., 2004). Following a feasibility study the two organisations entered into a partnership (SWISH) in 2003 to develop the system, based on infrastructure and a development team hosted in Edinburgh but managed by both organisations through the governance of the partnership.

\section{SWISH ACHIEVEMENTS}

Now in its 10th year, SWISH uses a shared IT infrastructure to deliver efficiency savings and develop and promote information on the historic environments of Wales and Scotland. Both organisations manage a range of information related to the historic environment (Figure 1) though the data model employed at RCAHMS is more expansive, with integrated bibliographic references and incorporating the database of Scottish radiocarbon dates as well as links to related designation information managed separately by Historic Scotland.

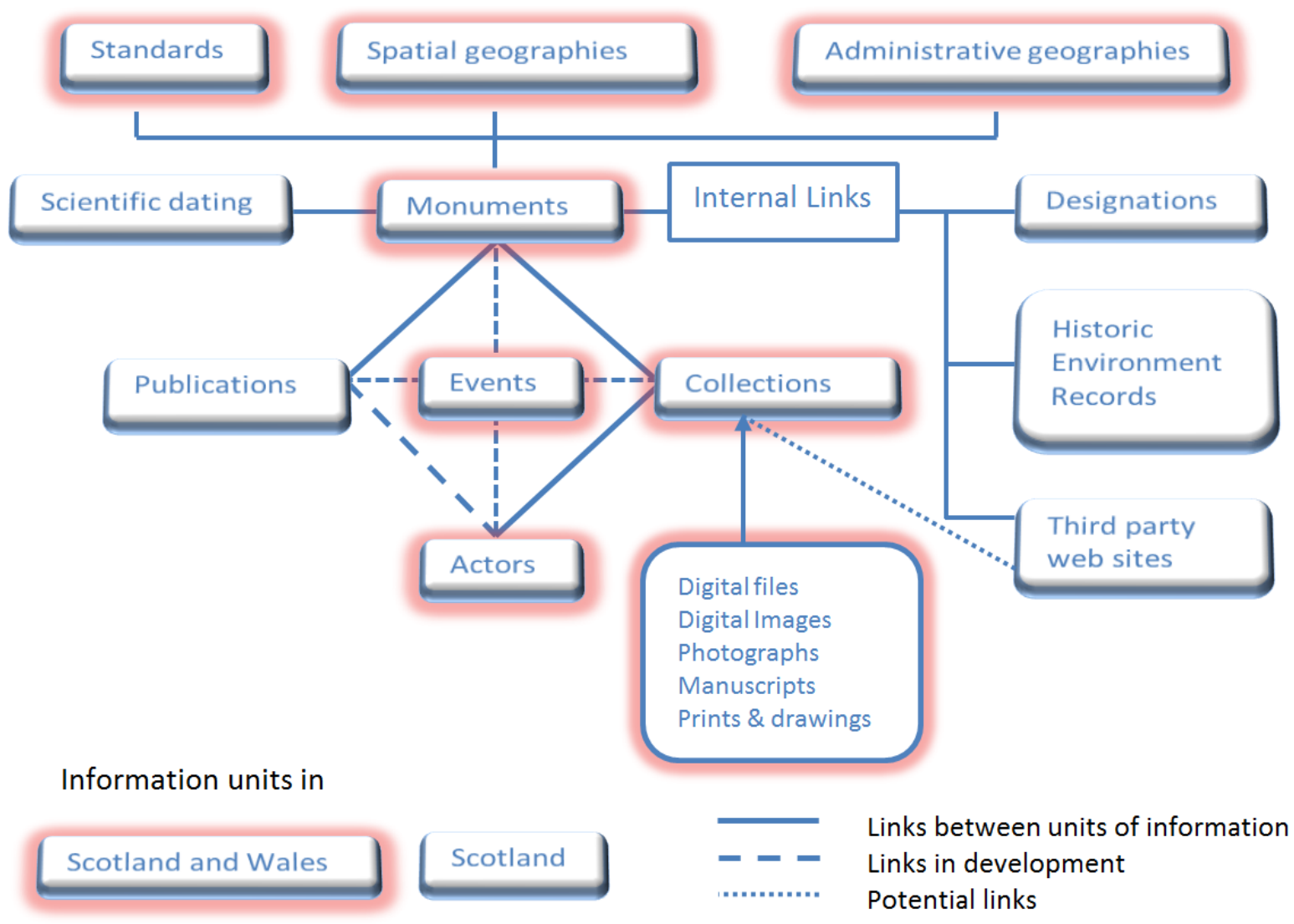

Figure 1: information units and links managed in the respective database 


\begin{tabular}{|c|c|c|c|}
\hline Year & RCAHMS & RCAHMW & Achievements \\
\hline 2001 & & RCAHMW Information Strategy review & \\
\hline 2002 & \multicolumn{2}{|c|}{ RCAHMW and RCAHMS Partnership Feasibility Study } & \\
\hline \multirow[t]{2}{*}{2003} & $\begin{array}{l}\text { Partnership agreed and work } \\
\text { commenced }\end{array}$ & $\begin{array}{l}\text { Specification of RCAHMW } \\
\text { requirements }\end{array}$ & \\
\hline & $\begin{array}{l}\text { Canmap: first web-map } \\
\text { browser launched }\end{array}$ & $\begin{array}{l}\text { Data cleansing in preparation for } \\
\text { migration }\end{array}$ & $\begin{array}{l}\text { Canmap wins Association of Geographic } \\
\text { Information (AGI) (Scotland) Award }\end{array}$ \\
\hline \multirow[t]{3}{*}{2004} & & Migration to Oracle database & \\
\hline & $\begin{array}{l}\text { PastMap ArcIms application } \\
\text { launched }\end{array}$ & Images added to Coflein & $\begin{array}{l}\text { Collaborative Web-Map Portal with Historic } \\
\text { Scotland and several local authority Historic } \\
\text { Environment records launched }\end{array}$ \\
\hline & Images added to Canmore & Coflein launched & \\
\hline \multirow[t]{2}{*}{2005} & & Mobile devices pilot & Testing mobile technology \\
\hline & $\begin{array}{l}\text { Shared solution for digital } \\
\text { archives established }\end{array}$ & $\begin{array}{l}\text { Shared solution for digital archives } \\
\text { established }\end{array}$ & \\
\hline 2006 & & Historic Wales launched & $\begin{array}{l}\text { Initially a collaboration between RCAHMW } \\
\text { and Amgeuddfa Cymru - National Museum } \\
\text { Wales. }\end{array}$ \\
\hline \multirow[t]{2}{*}{2006} & Online thesaurus released & Online thesaurus released & \\
\hline & & Redesign of RCAHMW Website & \\
\hline $\begin{array}{l}2006 \\
(?)\end{array}$ & $\begin{array}{l}\text { Online database developed } \\
\text { for Scottish Borders Council }\end{array}$ & & First hosted service \\
\hline 2007 & $\begin{array}{l}\text { Events and Actors modules } \\
\text { launched }\end{array}$ & Events and Actors modules launched & \\
\hline 2008 & $\begin{array}{l}\text { Scotland's Rural Past data } \\
\text { entry form }\end{array}$ & $\begin{array}{l}\text { Cadw's Scheduled Ancient Monuments } \\
\text { and Listed Building databases added to } \\
\text { Historic Wales }\end{array}$ & $\begin{array}{l}\text { Online staging form for Scotland's Rural Past } \\
\text { groups to enter data remotely }\end{array}$ \\
\hline \multirow[t]{2}{*}{2008} & $\begin{array}{l}\text { RCAHMS Centenary } \\
\text { celebrations }\end{array}$ & RCAHMW Centenary celebrations & \\
\hline & & Coflein re-launched & \\
\hline \multirow[t]{3}{*}{2009} & Canmore re-launched & & \\
\hline & MyCanmore launched & & User generated contributions: learning to let go: \\
\hline & & $\begin{array}{l}\text { Peoples Collection Wales Connector } \\
\text { developed }\end{array}$ & \\
\hline \multirow[t]{3}{*}{2010} & & $\begin{array}{l}\text { Collection Module (ISAD }(\mathrm{G}) \\
\text { compliant) for Wales }\end{array}$ & \\
\hline & $\begin{array}{l}\text { Collection Module } \\
\text { (ISAD(G) compliant) for } \\
\text { Scotland } \\
\end{array}$ & $\begin{array}{l}\text { All Welsh HER data added to Historic } \\
\text { Wales }\end{array}$ & \\
\hline & ScotlandsPlaces launched & & $\begin{array}{l}\text { Partnership with National Records of Scotland } \\
\text { and National Library of Scotland (Map Library) } \\
\text { Winner 'Most Beneficial Information Service' } \\
\text { at AGI (Scotland) }\end{array}$ \\
\hline \multirow[t]{3}{*}{2011} & $\begin{array}{l}\text { Canmore mapping } \\
\text { relaunched }\end{array}$ & $\begin{array}{l}\text { Live link to the HERs Archwilio } \\
\text { database established }\end{array}$ & Integrated map and database search \\
\hline & INSPIRE WMS published & & First publicly accessible WMS \\
\hline & SURE partnership launched & $\begin{array}{l}\text { Beta version of new Coflein mapping } \\
\text { launched }\end{array}$ & $\begin{array}{l}\text { Opening RCAHMS staff database to external } \\
\text { users }\end{array}$ \\
\hline \multirow[t]{2}{*}{2012} & & New Coflein Mapping re-launched & \\
\hline & \multicolumn{2}{|c|}{ Britain from Above (in partnership with English Heritage) } & Builds on skills developed through SWISH \\
\hline \multirow[t]{2}{*}{2013} & PastMap redeveloped & $\begin{array}{l}\text { Enhanced Catalogue Searching for } \\
\text { Coflein launched }\end{array}$ & $\begin{array}{l}\text { Rebuilt using Open Source software. Utilises } \\
\text { WFS where available. } \\
\text { Data freely downloadable }\end{array}$ \\
\hline & $\begin{array}{l}\text { INSPIRE WFS to be } \\
\text { released (by December 2013) }\end{array}$ & Historic Wales re-launch & First publicly accessible WFS \\
\hline
\end{tabular}

Table 1: timeline of SWISH developments

The partnership has developed a suite of products (Table 1), including an Oracle-based information management system for a wide range of data (Figure 1). Web services from Oracle are consumed by the web developers, working in partnership with designers, to create a range of web portals: Coflein (http://www.coflein.gov.uk) in Wales and Canmore in Scotland and their associated browser-based map interfaces. Successful delivery of web-GIS solutions for each Commission led to the development of collaborative web-map portals publishing other related datasets (PastMap (http://pastmap.org.uk/) and Historic Wales (www.historicwales.gov.uk), directly benefiting those managing the historic environment at national and local level. 
Initially developed through an ArcIms solution in 2004 and 2006 respectively, some of the functionality is not supported by modern browsers. As a result the partnership has redeveloped both portals using open source software. In addition to Canmore data PastMap, re-launched in 2013, now provides access to three statutory datasets from Historic Scotland as well as 25 out of 32 local authority Historic Environment Records (HERs). More datasets about Scotland's historic environment, including Conservation Areas and the Register of Historic Battlefields, will be added in due course. Historic Wales provides access to two designation datasets from Cadw, artefact locations from Amgeuddfa Cymru - National Museum Wales, and the HER data from each of the four Welsh Archaeological Trusts. Delivery of information in a map-based browser also led to the investigation of hand-held mobile access in Wales in 2005 through pilots in Ruthin, Blaenavon and Caerleon (Pert 2008). Records from Coflein were loaded on to a PDA (Portable Digital Assistant) device and mapped against Ordnance Survey digital data using a feed from GPS to track the user's location. The pilot has been used to develop trails and map searching in the Peoples Collection Wales project. Behind the scenes the partnership has delivered a number of technical projects including server, software and firewall upgrades, in addition to supporting production support calls and ongoing Oracle, Web and GIS maintenance. Broadening of skills and experience has enabled both primary partners to explore and exploit other innovative partnership opportunities and the partnership has gone beyond shared IT services and now encompasses shared working practices, strategies and skills development.

\section{FLEXIBILITY IN PARTNERSHIP}

The SWISH partnership forms a base on which the differing operational and business needs of the organisations can be supported and allows both organisations to react to and adopt new technologies, standards and working practices. A major new priority is the joint development of the digital archives as Trusted Digital Repositories. The work is in response to the recently published ISO 16363 standard that articulates the requirements for a digital archive to be considered trustworthy in a rapidly changing digital world. Under the SWISH partnership, the digital archive for RCAHMW is curated at RCAHMS and both organisations are looking to become the recognized repository for historic environment information in their respective countries.

Whilst both Commissions move forward towards common goals, the partnership also enables each organisation to develop their own approaches to information management independent of each other.

\subsection{Routes into Canmore}

In Scotland, working practices have evolved from the presentation of an authoritative account of the nation's heritage, with extensive restrictions on who could contribute and how, to the development of a collaborative digital environment. There are now several routes into Canmore, enabling a range of users to contribute, at a level they are comfortable with, to the national record (Hamilton et al. in press) - an approach, if not the mechanism, anticipated over 20 years ago by Ashmore (1992). The underlying philosophy acknowledges the separate requirements of partner organisations and the need to reduce duplication and the associated waste of resources, as well as the need to share information. It succeeds 'only in so far as it formalises a meeting of peers rather than attempting to accommodate a hierarchy of merit of power' (Ashmore 1992).

\subsubsection{Specialist User Recording Environment:}

Through the Specialist User Recording Environment (SURE), approved partners working remotely can now add information directly into the RCAHMS database. Building on an initial partnership with the National Trust for Scotland (NTS), project partners now include local government (City of Dundee Council and Orkney Islands Archaeology Service), national government (The Treasure Trove Unit (hosted by the NMS) and Scottish Canals) and a national society (the Garden History Society in Scotland), with many more in the pipeline. SURE partners can add or update records depending on privileges assigned on logging into the database, restricted to specific IP addresses, with access rights guaranteeing information added by one authority is not edited by another. Data content is added through the Events table, which stores the investigative history of a monument. Through this approach, differences in opinion and interpretation about a monument are able to be appropriately attributed or managed. Web services ensure that information so entered is published immediately on Canmore for the benefit of the public, reducing duplication from partners entering data into separate databases. The ethos behind this holding data once and using it many times - works towards a key Scottish Government requirement for spatial data (Scottish Government 2005). Moreover, as RCAHMS is responsible for maintenance, system upgrades, resolving technical issues and delivering national and international standards, partners may benefit from eliminating software licencing costs, greatly reduced burden on remote IT services and enabling heritage staff to concentrate on making information available to the public. Both the NTS and Scottish Canals have been successful in attracting funds for data enhancement on their respective estates through SURE, whilst Orkney Islands Council secured NESTA funding to develop web-based visitor materials using data from, and links to, Canmore (NESTA 2012).

3.1.2 Trusted User Environment: Complementing SURE, the Trusted User Environment was initially developed for Scotland's Rural Past (SRP) (http://scotlandsruralpast.org.uk/) which ran between 2006 and 2011. Working in partnership with RCAHMS field staff, community groups were able to report their project results remotely via a mediated online form delivered through Oracle Application Express. Again, users can create new, or contribute to existing, site records. On completion, information is held until checked by an approved validator, whereupon it is added to the RCAHMS database and published on Canmore. Latterly the form has been used by seasonal Ranger staff working on NTS properties, with validation undertaken by an NTS archaeologist as a SURE partner.

3.1.3 User Generated Comment and Content: At its simplest level, members of the public may add comments, or images directly to an existing site record or comment on images. User Generated Comments are an increasingly important part of an inventory, providing content and illustration to many records. By June 2013, the public had contributed over 29,000 images and over 1,700 comments have been added to 1,059 Records. Although presented separately from other events on Canmore, these observations are stored in the underlying Events and Notes table alongside other, more traditional recording events. 


\subsection{The Peoples Collection}

In Wales RCAHMW is a partner in the Peoples Collection (http://www.peoplescollectionwales.co.uk/), an online portal enabling cross-searching of documents, images, sound recordings and videos from several sources, including national institutions such as the National Library of Wales and Amgeuddfa Cymru - National Museum Wales. Information is provided as a feed from the RCAHMS servers in Edinburgh to the Peoples Collection API, and consists largely of images with accompanying descriptive metadata. The portal also enables user-generated content and has an active community engagement strand to generate new material from clubs, societies and community groups.

\subsection{ScotlandsPlaces}

A similar project in Scotland brings together information and images from RCAHMS' Canmore database with those supplied by the National Records of Scotland and the National Library of Scotland - Map Library (Beamer and Gillick 2010a). Developed and hosted at RCAHMS on behalf of the partners, ScotlandPlaces (http://www.scotlandsplaces.gov.uk/) uses web services in the form of parameterised URLs, to enable crossdomain querying, data retrieval and display via a bespoke XML standard (Beamer and Gillick 2010b). Using geography as a glue, visitors to the website can quickly retrieve information about a precise location presented alongside digitised volumes of, for example, tax returns by a county.

\subsection{Web Map Services and Web Feature Services}

The development of Web Map (WMS) and Web Feature Services (WFS) enables both organisations to publish spatial information through their respective web-GIS portals. WMS are now routinely used to publish content and provide background mapping across the range of web-GIS browsers hosted by both organisations. For the redevelopment of PastMap and Historic Wales, WFS services are being used for the first time, where available, to provide data content.

In addition RCAHMS has published the metadata and WMS for its site location data through Scotland's Spatial Data Infrastructure portal which is harvested by data.gov.uk and, in turn, the INSPIRE Geoportal, enabling remote users to consume services directly into their desktop GIS. As part of its commitment to INSPIRE, RCAHMS intend to release a WFS for the Canmore point data by December 2013. Through SWISH, the lessons learned and knowledge gained in implementing WMS and WFS for Scotland, remain in-house to assist Wales when they are ready to release similar services,

\section{TO THE FUTURE}

Much has changed in the 10 years since SWISH was launched. What started out as a pragmatic solution for providing an online database for RCAHMW, has evolved to enable both organisations to develop their systems, publish online and share data with other portals through APIs and web services at a pace they are comfortable with.

Delivery of information through our web portals, and increasingly as feeds to external portals not only presents much more material online, but we now reach a far wider audience than could ever be achieved through traditional publications and visits to our respective search rooms. In providing accessible inventories, public awareness and appreciation of their heritage is increased. In Scotland, accessible records help deliver a key indicator of the National Performance Framework (Scottish Government 2011), that we value and enjoy our built and natural environment and enhance it for future generations'.

Both organisations have a strong track record in publishing information through web portal, presented in formats easily understood by the public. However, the potential of the data contained within the databases has yet to be fully realised in the Web of Data. In part, SWISH priorities lie elsewhere, in developing applications to meet immediate needs, such as implementing the TDR or introducing sophisticated search and retrieval tools for the collections. The research required to implement Linked Data approaches is also time consuming and beyond existing internal resources, but forms an ideal subject for academic research. An extract of RCAHMS data formed a key case study in Bryne's Ph.D. research into the semantic web (Byrne 2008) in which she explored creating a coherent body of information from various structured and unstructured formats. Through the University of South Wales, both organisations and English Heritage are currently contributing their monument and other thesauri to the SENESCHAL, project (http://hypermedia.research.southwales.ac.uk/kos/SENESCHAL I (accessed 3 July 2013)). SENESCHAL will establish persistent URIs for our key vocabularies and represents a significant first step into the Web of Data.

Although the SWISH partnership is now 10 years old, the underlying database structure is based on schema designed 10 years earlier. Prompted by the need to overhaul existing systems, RCAHMS has launched an ambitious project to review, and redevelop systems and services - the Collaborative Organisational Resource, Preservation and User System, or CORPUS. To date CORPUS has reviewed the existing systems and workflows and identified 14 key areas to consider in taking the redevelopment forward (Figure 2).

\section{Where We Are Now}

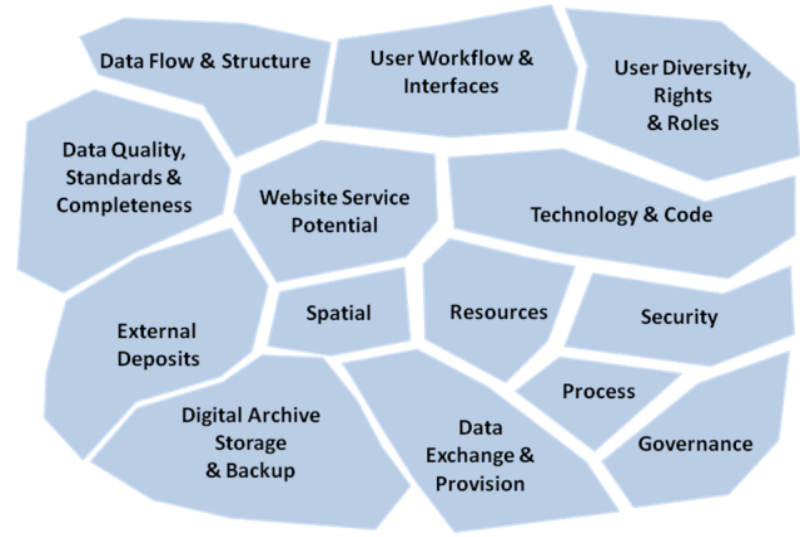

Figure 2: Key elements in CORPUS

The existing Oracle Forms database will be redeveloped in Oracle APEX, providing more flexible web delivery for SURE partners, streamlined workflow processes and interfaces. The RCAHMS website will also be redesigned with greater emphasis on promoting key services, including Canmore. RCAHMW are also intending to redesign their website. Continuing the theme of shared development, RCAHMW will benefit from the CORPUS programme and will be exploring 
ways of implementing the outputs into their own streamlining of systems and workflows.

Looking to the future, both Royal Commissions are facing organisational changes, but the effectiveness of the SWISH partnership in delivering core functions has been recognised by decision-makers in both countries. This should ensure that the essential business of both organisations, including the development of the site inventory and the digital archive, will continue to be well supported through a period of change.

\section{References}

Ashmore, P.J., 1992. Coping with Diversity through Harmonisation. in Larsen, C.U. (ed) Sites and Monuments. National Archaeological Records. The National Museum of Denmark, DKC. pp 217-9.

Beamer, A and Gillick, M., 2010a. Scotlandsplaces: Accessing Remote Digital Heritage Datasets using Web Services. In Ioannides, M., Fellner, D., Georgopoulos, A., Hadjimitsis, D.G. (eds) Digital Heritage - Third International Conference, EuroMed 2010 LNCS vol. 6436, pp.225-239. Springer, Heidelberg (2010). doi: 10.1007/978-3-642-16873-4 17 (24 Jun 2013)

Beamer, A and Gillick, M., 2010b ScotlandsPlaces XML: Bespoke XML or XML Mapping? In Program: Electronic Library and Information Systems, 44 (1) pp.13-27. doi: 10.1108/00330331011019654 (24 Jun 2013)

Byrne, K., 1999. Providing Access to the National Monuments Record of Scotland. In: Dingwall, L., S. Exon, V. Gaffney, S. Laflin and M. van Leusen (eds.) Archaeology in the Age of the Internet. CAA97. Computer Applications and Quantitative Methods in Archaeology. Proceedings of the 25th Anniversary Conference, University of Birmingham, April 1997 (BAR International Series 750). Archaeopress, Oxford, pp. 201-204. http://caaconference.org/proceedings/paper/32_byrne_caa_1997 I (5 July 2013).

Byrne, K., 2008. Populating the semantic web: combining text and relational databases as RDF graphs. Ph.D. Edinburgh University. http://hdl.handle.net/1842/3781 (3 Jul 2013).

Dunbar, J., 1992. The Royal Commission on the Ancient and Historical Monuments of Scotland: the first eighty years. Transactions of the Ancient Monuments Society 36, 13-77.

Hamilton, S., Jones, R., and McKeague, P., in press. Old Places, New Ideas: New Routes into Canmore, the National Inventory of Scotland. In Earl, G., Sly, T., Chrysanthi, A., Murrieta-Flores, P., Papadopoulos,C., Romanowska, I and Wheatley, D. (eds) Proceedings of the $40^{\text {th }}$ Annual Conference of Computer Applications and Quantitative Methods in Archaeology (CAA), Southampton, England, Amsterdam: Amsterdam University Press.

Malaws, H., McCoy, J., and Murray, M., 2004. Shared Web Information Services. Royal Commission on the Ancient and Historical Monuments of Scotland, Annual review 2003-2004. RCAHMS, Edinburgh, United Kingdom, pp 68-73.

Murray, D., 1992. Towards Harmony. A view of the Scottish Archaeological Database. In Larsen, C.U. (ed) Sites and
Monuments. National Archaeological Records. The National Museum of Denmark, DKC. pp 209-216.

NESTA. 2012. Scottish local authorities open up data to tackle community issues.

http://www.nesta.org.uk/press_releases/assets/features/scottish_1 ocal authorities open up data to tackle community issues (3 Jul 2013).

Nikolic, L.P. 1999. New Developments at the RCAHMW. In: Dingwall, L., S. Exon, V. Gaffney, S. Laflin and M. van Leusen (eds.) Archaeology in the Age of the Internet. CAA97. Computer Applications and Quantitative Methods in Archaeology. Proceedings of the 25th Anniversary Conference, University of Birmingham, April 1997 (BAR International Series 750). Archaeopress, Oxford, pp. 205-208. http://caaconference.org/proceedings/paper/33_nikolic_caa_199 7/ (5 July 2013).

Pert, T. 2008. History in Your Hand: Using Mobile Devices in Heritage Interpretation. RCAHMW, Aberystwyth, United Kingdom.

Scottish Government. 2005. One Scotland, One Geography; a geographic information strategy for Scotland. http://www.scotland.gov.uk/publications/2005/08/31114408/44 $\underline{098}$ (5 July 2005).

Scottish Government, 2011. Scotland Performs. http://www.scotland.gov.uk/About/Performance/scotPerforms (3 Jul 2013).

\section{Acknowledgements}

Established through the vision of Peter White and Roger Mercer, who were the Secretaries (Chief Executives) of RCAHMW and RCAHMS, the SWISH partnership continues to grow through the support and encouragement of the present Secretaries, Peter Wakelin and Diana Murray. The partnership would not have been possible without the tireless efforts of many staff from both organisations particularly Angela Gannon, Mark Gillick, Rebecca Jones, Jo McCoy and Miriam McDonald (RCAHMS) and Hilary Malaws and Gareth Edwards (RCAHMW). Oracle development work has been led by Graham Ritchie with Christine Allen, Derek Skinner and Frank Wilhelm whilst the GIS is managed by Alistair Wilkie. Websites were created through the efforts of Alasdair Burns, Cole Henley, Lisa McGuickin, Keith Rooney and Zeno Kerr. The CORPUS redevelopment is being led Alex Adamson and Leanne McCafferty and the authors are grateful for sight of their report. Whilst SWISH is a partnership between Scotland and Wales, individual projects have benefited from shared knowledge with colleagues at English Heritage, particularly Paul Adams, Phillip Carlisle, and Keith May. SWISH engagement with the Semantic Web would not be possible without the expertise of Professor Douglas Tudhope and Ceri Binding at the University of South Wales. Finally, the authors are grateful to Susan Hamilton, Kirsty Lingstadt and Robin Turner for commenting on earlier drafts of the paper. 